\title{
Long term precipitation trends and variability within the Mediterranean region
}

\author{
C. M. Philandras ${ }^{1}$, P. T. Nastos ${ }^{2}$, J. Kapsomenakis ${ }^{1}$, K. C. Douvis ${ }^{1}$, G. Tselioudis ${ }^{1}$, and C. S. Zerefos ${ }^{1,2}$ \\ ${ }^{1}$ Research Center of Atmospheric Physics and Climatology, Academy of Athens, Greece \\ ${ }^{2}$ Laboratory of Climatology and Atmospheric Environment, Faculty of Geology and Geoenviroment, National and \\ Kapodistrian University of Athens, Greece
}

Received: 28 March 2011 - Revised: 3 October 2011 - Accepted: 10 October 2011 - Published: 10 December 2011

\begin{abstract}
In this study, the trends and variability of annual precipitation totals and annual rain days over land within the Mediterranean region are analyzed. Long term groundbased observations concerning, on one hand, monthly precipitation totals (1900-2010) and rain days (1965-2010) from 40 meteorological stations within the Mediterranean region were obtained from the Hellenic National Meteorological Service and the World Climate Data and Monitoring Programme (WCDMP) of the World Meteorological Organization. On the other hand, high spatial resolution $\left(0.5^{\circ} \times 0.5^{\circ}\right)$ gridded monthly data CRU TS 3.1 were acquired from the Climatic Research Unit, University of East Anglia, for the period 1901-2009. The two datasets were compared by means of trends and variability, while the influence of the North Atlantic Oscillation (NAO) in the Mediterranean precipitation was examined. In the process, the climatic changes in the precipitation regime between the period 1961-1990 (reference period) and the period 2071-2100 (future climate) were presented using climate model simulations (RACMO2.1/KNMI). The future climate projections were based on SRES A1B.

The findings of the analysis showed that statistically significant (95\% confidence level) negative trends of the annual precipitation totals exist in the majority of Mediterranean regions during the period 1901-2009, with an exception of northern Africa, southern Italy and western Iberian peninsula, where slight positive trends (not statistically significant at $95 \% \mathrm{CL}$ ) appear. Concerning the annual number of rain days, a pronounced decrease of $20 \%$, statistically significant (95\% confidence level), appears in representative meteorological stations of east Mediterranean, while the trends are insignificant for west and central Mediterranean. Additionally, NAO index was found to be anticorrelated with the
\end{abstract}

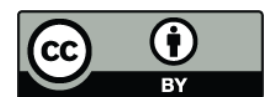

Correspondence to: P. T. Nastos (nastos@geol.uoa.gr) precipitation totals and the number of rain days mainly in Spain, southern France, Italy and Greece. These correlations are higher within the rain season (October-March) than the entire year. Based on the results of regional climate model RACMO2.1/KNMI, precipitation is very likely to decrease almost $20 \%$ in the period 2071-2100 compared to 19611990, under SRES A1B.

\section{Introduction}

In recent years, there is a great consensus among the scientific community concerning the variability and trends of precipitation and their effects on the environment during the 20th century (Karl and Knight, 1998; Folland and Karl, 2001; Zhang et al., 2001). For Europe, the precipitation trend appears to be positive in the northern (Forland et al., 1996; Schonwiese and Rapp, 1997) and negative in the south (Schonwiese and Rapp, 1997).

The Mediterranean region comprises the lands around the Mediterranean Sea that have a Mediterranean climate as part of Subtropical climate, which is characterized by hot, dry, sunny summers and a winter rainy season (Csa, Csb, according to Koppen classification); basically, this is the opposite of a monsoon climate and seems to be more sensitive to changes in global warming with a significant impact on the parameter of precipitation. The analysis of cyclone climatology in the Mediterranean region shows trends and a moderate response to future emission scenarios. The main signal is associated with a decrease of cyclone frequency during winter in the western Mediterranean region, presumably associated with a northward shift of the storm track and persistent high phase of NAO index (Hurrell and van Loon, 1997). Such decline of cyclone frequency is suggested to continue as green house gas concentration increases, as shown by scenario simulations (Ulbrich and Christoph 1999, Lionello et al., 2002). According to the results of climatic models (SRES A1B), it

Published by Copernicus Publications on behalf of the European Geosciences Union. 
is very likely that during the period 2080-2099, precipitation will shift northwards while decreases of more than $20 \%$ over the reference period 1980-1999 will appear (IPCC, 2007) at southern Mediterranean regions. The SRES A1 storyline (IPCC, 2007) assumes a world of very rapid economic growth, a global population that peaks in mid-century, and rapid introduction of new and more efficient technologies. A1 is divided into three groups that describe alternative directions of technological change: fossil intensive (A1FI), non-fossil energy resources (A1T), and a balance across all sources (A1B). Accordingly, Tselioudis et al. (2008), based on the results of climatic models, showed a marked decrease in winter precipitation within the Mediterranean region - almost $20 \%$ by the end of the 21 st century. However, cyclone activity presents large seasonal and spatial variability, with large differences from western to eastern Mediterranean and between cold and warm seasons (Lionello et al., 2006). The majority of the Mediterranean region has tended toward decreasing winter precipitation during the last few decades, mostly starting in the 1970s and proceeding to an accumulation of dry years in the 1980s and 1990s (Schonwiese et al., 1994; Palutikof et al., 1996; Piervitali et al., 1997; Schonwiese and Rapp, 1997). The west-central Mediterranean area has experienced a precipitation decrease during the last $50 \mathrm{yr}$ (Piervitali et al., 1997). Trends are not uniform and interdecadal variability is high. The different characteristics of the western and eastern Mediterranean and high interdecadal variability are presumably the source of some disagreement. In fact, other studies suggest no actually significant trend, an increase of weak cyclones in the western Mediterranean in the period 1978-1994 (Trigo et al., 2000), a positive trend in the eastern Mediterranean, though not in the rainy season (Maheras et al., 2001). Nevertheless, in a $45 \mathrm{yr}$ record, Guijarro et al. (2006), show a significant decrease in the cyclonic circulation in the western Mediterranean, and an increase in the eastern Mediterranean.

Precipitation trends and variability within the eastern Mediterranean and Greece in particular have been studied by many researchers (Repapis, 1986; Maheras and KolyvaMahera, 1990; Mantis et al., 1994; Metaxas et al., 1999, Brunetti et al., 2001, Paliatsos et al., 2005; Pnevmatikos and Katsoulis, 2006; Feidas et al., 2007; Nastos and Zerefos, 2007, 2008; Nastos, 2008).

The objective of this study is to analyze, on one hand, the trends and variability of long term time series of precipitation totals and annual number of rain days based on groundbased and gridded (CRU TS 3.1) monthly observations over land in the Mediterranean region, as well as the influence of atmospheric circulation, by means of NAOI. On the other hand, precipitation projections for the future climate (20712100) under SRES A1B were carried out using simulations from RACMO2.1/KNMI model. The SRES A1B was chosen because it is considered an average scenario and it is mostly acceptable for future projections, according to the scientific literature. Moreover, the future projections derived by
RACMO2.1/KNMI (ENSEMBLES Deliverable D3.2.2) are based only on A1B scenario.

\section{Data and analysis}

The trends and variability of annual precipitation totals within the Mediterranean region were analyzed for two periods - one concerning the period 1901-2009 and the other the period 1951-2009 - using, on one hand, the gridded monthly precipitation data CRU TS 3.1 (Climatic Research Unit, University of East Anglia) with spatial analysis $0.5^{\circ} \times 0.5^{\circ}$, covering all land areas of the Earth (continental areas and some large islands) with the exception of the Antarctic region (Mitchell and Jones, 2005). These datasets were constructed using precipitation totals and air temperature from many meteorological stations around the world that have been tested for reliability and homogeneity. More specifically, for the period 1961-1990, the network of meteorological stations whose data were used to create the CRU TS 3.1 includes more than 8000 stations worldwide with temperature and more than 6000 with precipitation data. This network is denser in overpopulated areas like Europe, where more than 800 stations were used for air temperature and more than 600 stations for precipitation totals. In addition, estimates are made of the uncertainties caused by poor measurements, uncertainties in the station data, sampling uncertainties caused by the limited number of measurements available, and largescale biases such as urbanisation. The following briefly describes the steps taken to create the gridded specific datasets: at first, for each station, the mean air temperature and precipitation for the period 1961-1990 were calculated for each month (New et al., 1999). Thereafter, the time series of monthly anomalies from the mean of the period 1961-1990 were calculated for each station for the period 1901-2009. Then the derived time series were adjusted into a grid with spatial resolution $0.5^{\circ} \times 0.5^{\circ}$, using statistical interpolation methodology. In the process, the time series were corrected for each grid point, in order that the mean anomaly of air temperature and precipitation for the control period 1961-1990 is equal to zero. Finally, for each grid point, the mean values of the period 1961-1990 were added to the anomaly time series (New et al., 1999, 2000; Mitchell and Jones, 2005).

On the other hand, monthly precipitation totals from 40 meteorological stations within the Mediterranean region (Table 1) were acquired from the monthly climatological bulletins of Hellenic National Meteorological Service (HNMS), while the European monthly precipitation datasets for the period 1990-2010 were acquired from the monthly Climatic Data for the World (http://www7.ncdc.noaa.gov/ IPS/mcdw/mcdw.html), and for the period 1900-1990 from WORLD CLIMATIC DISC, Global Climatic Change Data, CHADWYCK-HEALEY, Climatic Research Unit at the University of East-Anglia. Additionally, the annual number of rain days (days with precipitation greater than $1 \mathrm{~mm}$ ) were 
Table 1. Trends of annual precipitation totals and annual number of rain days. The figures in brackets concern trends of annual precipitation totals during the 1951-2010. The asterisk (*) denotes statistically significant figures at $95 \%$ confidence level. Column 5 refers to the available period of recorded annual precipitation and column 7 to the available period of annual number of rain days.

\begin{tabular}{|c|c|c|c|c|c|c|c|}
\hline & Station & Longitude & Latitude & Period & $\begin{array}{r}\text { Trend of annual } \\
\text { Precipitation } \\
\left(\mathrm{mm} \mathrm{yr}^{-1}\right)\end{array}$ & Period & $\begin{array}{r}\text { Trend of annual } \\
\text { number of rain days } \\
\left(\text { days } \mathrm{yr}^{-1}\right)\end{array}$ \\
\hline 1 & Gibraltar & -5.12 & 36.09 & 1900-2010 & $-0.68(0.97)$ & 1965-2010 & $3.5 \times 10^{-2}$ \\
\hline 2 & Alicante & -0.30 & 38.22 & $1951-2010$ & -1.18 & 1965-2010 & $7.3 \times 10^{-2}$ \\
\hline 3 & Oran & 0.36 & 35.38 & 1900-2010 & $-0.64(-2.02 *)$ & & \\
\hline 4 & Barcelona & 2.09 & 41.24 & 1951-2010 & $\left(-3.66^{*}\right)$ & 1965-2010 & -0.16 \\
\hline 5 & Perpinian & 2.53 & 42.44 & 1900-2010 & $-2.76 *(-6.67 *)$ & & \\
\hline 6 & Menorca & 4.14 & 39.52 & 1951-2010 & -1.21 & 1965-2010 & $-6.1 \times 10^{-2}$ \\
\hline 7 & Nice & 7.12 & 43.39 & 1951-2010 & $-4.33 *$ & & \\
\hline 8 & Ajjacio & 8.48 & 41.55 & 1900-2010 & $-3.68 *(-9.2 *)$ & & \\
\hline 9 & Tunis & 10.14 & 36.50 & 1900-2010 & $0.98 *(-0.82)$ & 1965-2010 & $3.3 \times 10^{-2}$ \\
\hline 10 & Trapani & 12.30 & 37.55 & $1961-2010$ & -0.83 & 1965-2010 & 0.2 \\
\hline 11 & Malta & 14.29 & 35.51 & 1900-2010 & $0.61(-0.86)$ & 1965-2010 & $8.6 \times 10^{-2}$ \\
\hline 12 & Messina & 15.33 & 38.12 & $1961-2010$ & 0.64 & 1965-2010 & -0.11 \\
\hline 13 & Kerkyra & 19.55 & 39.37 & 1900-2010 & $-1.7^{*}\left(-4.35^{*}\right)$ & 1965-2010 & $-0.87 *$ \\
\hline 14 & Ioannina & 20.49 & 39.42 & 1951-2010 & $-5.62 *$ & 1965-2010 & $-0.72 *$ \\
\hline 15 & Argostoli & 20.50 & 38.12 & 1955-2010 & $-8.83^{*}$ & & \\
\hline 16 & Agrinio & 21.23 & 38.37 & 1951-2010 & $-4.73 *$ & 1965-2010 & -0.26 \\
\hline 17 & Araxos & 21.42 & 38.15 & 1951-2010 & -1.22 & 1965-2010 & -0.21 \\
\hline 18 & Methoni & 21.42 & 36.50 & 1935-2010 & $-3.15 *(-3.09 *)$ & & \\
\hline 19 & Rhodes & 21.44 & 36.24 & 1951-2010 & $-5.4^{*}$ & 1965-2010 & $-0.58 *$ \\
\hline 20 & Kozani & 21.50 & 40.18 & 1950-2010 & $-5.28 *(-5.28 *)$ & & \\
\hline 21 & Kalamata & 22.01 & 37.04 & 1950-2010 & $-2.31 *(-2.27 *)$ & 1965-2010 & $-0.32 *$ \\
\hline 22 & Samos & 22.01 & 37.42 & $1951-2010$ & $-5.02 *$ & 1965-2010 & $-0.70 *$ \\
\hline 23 & Larissa & 22.25 & 39.38 & 1900-2010 & $-0.79 *(-0.70)$ & 1965-2010 & $-0.35^{*}$ \\
\hline 24 & Tripolis & 22.40 & 37.52 & 1949-2010 & $-3.75^{*}(-3.68 *)$ & 1965-2010 & $-0.31 *$ \\
\hline 25 & Thessaloniki & 22.57 & 40.37 & 1931-2010 & $-0.94 *(-0.84)$ & 1965-2010 & $-0.45^{*}$ \\
\hline 26 & Kythira & 22.98 & 36.15 & 1949-2008 & $-1.55 *(-1.8 *)$ & 1965-2010 & $-0.46^{*}$ \\
\hline 27 & Athens (NOA) & 23.43 & 37.58 & 1900-2010 & $0.06(0.45)$ & 1965-2010 & -0.14 \\
\hline 28 & Helliniko & 23.44 & 37.54 & 1931-2010 & $-0.25(-0.44)$ & 1965-2010 & $-0.26^{*}$ \\
\hline 29 & Skyros & 24.48 & 38.97 & 1951-2010 & $-2.69 *$ & & \\
\hline 30 & Limnos & 25.04 & 39.53 & 1929-2010 & $0.20(1.14)$ & 1965-2010 & $-0.40 *$ \\
\hline 31 & Heraklion & 25.11 & 35.20 & 1947-2010 & $-0.35(-0.40)$ & 1965-2010 & -0.14 \\
\hline 32 & Naxos & 25.37 & 37.10 & 1955-2010 & 1.24 & & \\
\hline 33 & Alexandroupolis & 25.95 & 40.85 & 1947-2010 & $-1.26(-1.79 *)$ & 1965-2010 & $-0.53 *$ \\
\hline 34 & Canakale & 26.24 & 40.08 & 1929-2010 & $-4.09 *(-1.69)$ & 1965-2010 & -0.15 \\
\hline 35 & Edirne & 26.34 & 41.40 & 1929-2010 & $0.11(-0.12)$ & 1965-2010 & $-3.0 \times 10^{-2}$ \\
\hline 36 & Mytilini & 26.6 & 39.05 & $1952-2010$ & $-2.87 *$ & 1965-2010 & $-0.33 *$ \\
\hline 37 & Mougla & 28.22 & 37.13 & 1935-2010 & $-3.56\left(-2.15^{*}\right)$ & 1965-2010 & -0.24 \\
\hline 38 & Isparta & 30.33 & 37.45 & 1951-2010 & $-7.4 \times 10^{-2}$ & 1965-2010 & $-8.7 \times 10^{-2}$ \\
\hline 39 & Antalya & 30.44 & 36.52 & 1929-2010 & $0.23(0.22)$ & 1965-2010 & -0.18 \\
\hline \multirow[t]{4}{*}{40} & Larnaca & 33.38 & 34.53 & 1951-2010 & -0.73 & & \\
\hline & West Mediterranean & & & $1951-2010$ & $-3.61 *$ & 1965-2010 & $-2.7 \times 10^{-2}$ \\
\hline & Central Mediterranean & & & $1951-2010$ & $-3.01 *$ & 1965-2010 & $2.8 \times 10^{2}$ \\
\hline & East Mediterranean & & & $1951-2010$ & -1.50 & 1965-2010 & $-0.28 *$ \\
\hline
\end{tabular}


examined for trends and variability for the period 19652010. The trends for both the gridded and ground-based datasets were calculated using the Mann-Kendall methodology (Sneyers, 1975).

The influence of atmospheric circulation in the gridded and ground-based precipitation variability is examined with respect to North Atlantic Oscillation Index, which is defined as a difference of standardized sea level pressure (SLP) time series from a station close to the centre of the Azores High (Gibraltar) and a station close to the centre of Islandic Low (Reykjavik) (Jones et al., 1997).

Finally, future precipitation projections from the regional simulation model (RACMO2.1/KNMI) were used in order to estimate the annual precipitation changes within the Mediterranean between the period 1961-1990 (reference period) and 2071-2100 (future climate). The assessment of future climate made for the emission scenario A1B. RACMO2.1/KNMI (van Meijgaard et al., 2008) is based on the ECMWF physics cycle $28 \mathrm{r} 4$, which has been used for the ERA-40 re-analysis project. This physics package consists of the mass flux scheme by Tiedtke (1989) (including many updates), a prognostic cloud scheme by Tiedtke (1993), and tiled land surface scheme TESSEL, including four soil layers (both for soil moisture and temperature) and a skin temperature. In order to reduce the temperature bias in summer, the vegetation stress function has been modified and the thickness of the soil layers has been increased (to nearly $3.94 \mathrm{~m}$ in total) as described in Lenderink et al. (2003). RACMO2.1 uses the HIRLAM (6.3.7) advanced Semi-Lagrangian dynamical core and runs at a resolution of 0.22 degrees. The domain has 206 points in longitudinal direction and 224 in latitudinal direction. The model uses 40 vertical levels. The boundary layer update interval is $6 \mathrm{~h}$.

The RACMO2.1/KNMI simulation presented in this study concerns dynamic downscaling of ECHAM5 GCM. More specifically, the RACMO2.1/KNMI has been forced with six hourly lateral boundary conditions provided from ECHAM5.

\section{Results and discussion}

\subsection{Trends and variability based on historical data}

The mean annual precipitation from gridded datasets (CRU TS 3.1) for the Mediterranean over land for the periods 1901-2009 and 1951-2009 is depicted in Fig. 1 (upper and lower graphs respectively). The mean annual precipitation for both examined periods exhibits similar patterns in the Mediterranean over land. High precipitation totals (1000$2400 \mathrm{~mm}$ ) appear in eastern coastal areas of Adriatic and Ionian Sea, Croatia, Slovenia and northern Italy (especially southern Alps), mainly due to mountain forcing and local cyclogeneses. Furthermore, the eastward moving depressions from the Atlantic Ocean generate high precipitation totals $(1000-1600 \mathrm{~mm})$ over the northwest Iberian peninsula and southwest France. Less precipitation totals $(100-500 \mathrm{~mm})$ appear in the northern coastal areas of Africa and Spain mainland $(300-500 \mathrm{~mm})$, with an exception of Italian peninsula, Middle East, western coastal Turkey and Greece (400$800 \mathrm{~mm}$ ).

Taking into consideration the rain season (OctoberMarch), Fig. 2 presents the mean precipitation from gridded datasets (CRU TS 3.1) for the periods 1901-2009 (upper graph) and 1951-2009 (lower graphs). The spatial pattern of precipitation totals during the rain season is similar to the annual pattern, giving evidence that the rain season drives the precipitation for the entire year. High precipitation totals $(400-1100 \mathrm{~mm})$ appear in eastern coastal areas of Adriatic and Ionian Sea, Croatia, Slovenia and northern Italy (especially southern Alps). Less precipitation totals (200$400 \mathrm{~mm}$ ) appear in the rest of the Mediterranean.

The trends of the gridded time series (CRU TS 3.1) of the annual precipitation totals for the period 1901-2009 are presented in Fig. 3 (upper graph). Marked areas with an asterisk concern areas where trends are statistically significant at $95 \%$ confidence level (CL). Decreasing trends (0.8$1.6 \mathrm{~mm} \mathrm{yr}^{-1}$, statistically significant at $95 \% \mathrm{CL}$ ) appear at western and southwestern Mediterranean region (northern Africa and southern Iberian, while these trends are stronger in the north-eastern Morocco. On the other hand, however, farther north (western and northern Iberian, southwestern France) the annual precipitation show statistically significant $(95 \% \mathrm{CL})$ positive trends $\left(1.2-4.0 \mathrm{~mm} \mathrm{yr}^{-1}\right)$. Eastward, slight positive trends (not statistically significant at $95 \%$ CL) appear particularly in the area of northern Africa, the region of Calabria and western Sicily, while decreasing precipitation trends $\left(0.8-1.8 \mathrm{~mm} \mathrm{yr}^{-1}\right)$ statistically significant $(95 \%$ CL) are observed northward to the Italian peninsula, Sardinia and Slovenia, Croatia. Throughout the eastern Mediterranean, annual precipitation shows a statistically significant (95\% CL) decreasing trend $\left(0.8-1.2 \mathrm{~mm} \mathrm{yr}^{-1}\right.$ ), with the exception of northern Asia Minor and Eastern Thrace.

Figure 3 (lower graph) depicts the trends of gridded annual precipitation totals (CRU TS 3.1) for the period 1951-2009. During this period, it is remarkable that almost the entire Mediterranean, from the eastern Iberian to Palestine, shows a statistically significant $(95 \% \mathrm{CL})$ decrease in annual precipitation totals $\left(2.0-6.0 \mathrm{~mm} \mathrm{yr}^{-1}\right)$, much more pronounced than within the period 1901-2009, especially in northwest Africa, Italian and Greek peninsula. On the other hand, the region of north Africa from $15^{\circ} \mathrm{E}$ to $30^{\circ} \mathrm{E}$ longitude appears increasing trends $\left(0.8-1.8 \mathrm{~mm} \mathrm{yr}^{-1}\right)$, which are statistically significant (CL 95\%). Additionally, significant increasing trends $\left(1.0-4.0 \mathrm{~mm} \mathrm{yr}^{-1}\right)$ appear in the region of Calabria (Italy), a fact that is inconsistent with the areal pattern, and could be attributed to few particular data from CRU TS 3.1 gridded datasets. In a recent work, Brunetti et al. (2010), studying the precipitation variability and change in the Calabria, found that a general negative trend, albeit not everywhere significant, was detected, in particular for the autumn-winter 

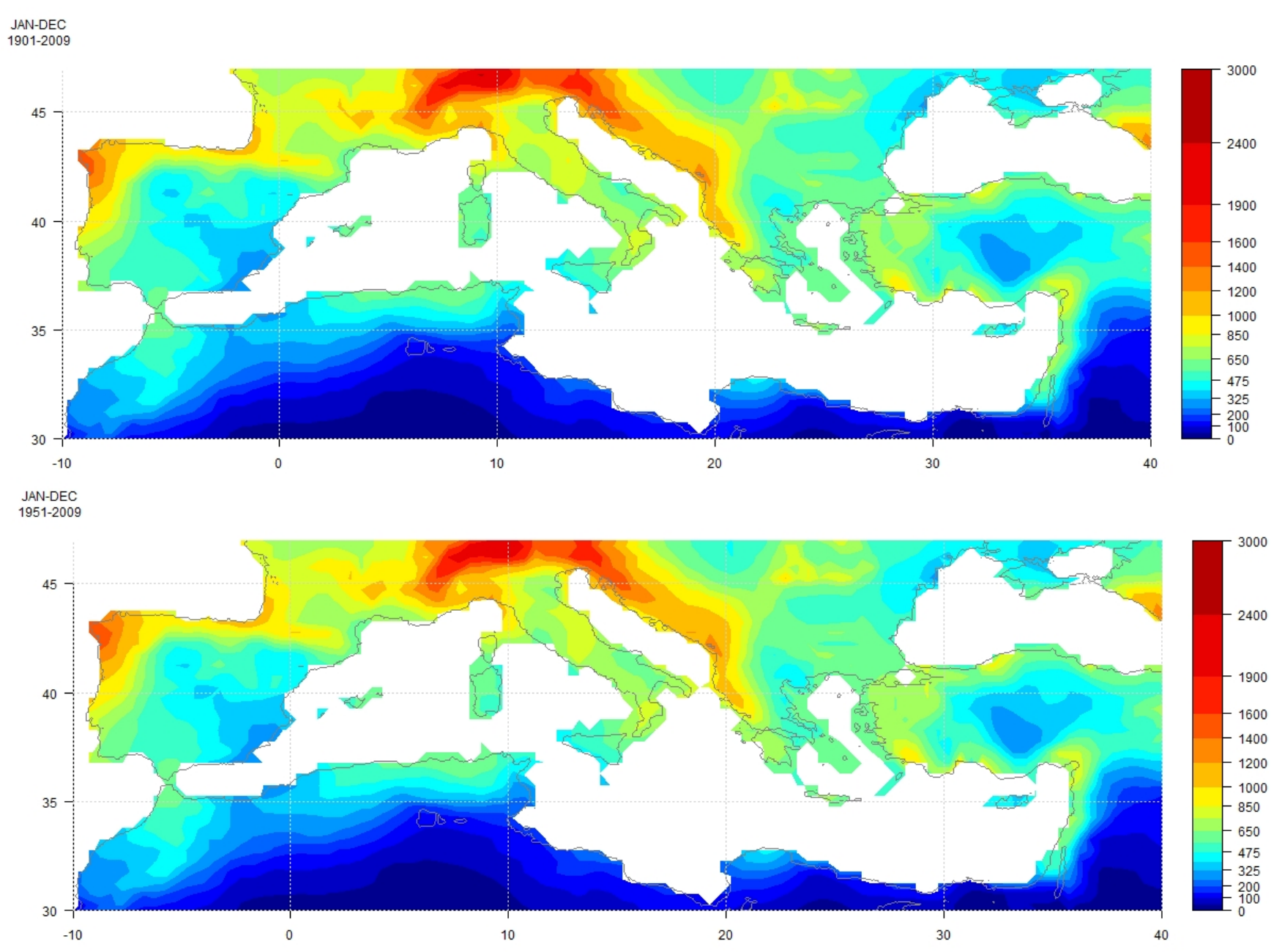

Fig. 1. Spatial distribution of mean annual precipitation concerning gridded datasets (CRU TS 3.1), for 1901-2009 (upper graph) and 1951-2009 (lower graph).

period, while in summer the tendency was toward an increase in total precipitation. With respect to rain season (October-March), Fig. 4 depicts the precipitation trends concerning gridded datasets (CRU TS 3.1) for 1901-2009 (upper graph) and 1951-2009 (lower graph). Interpreting the resulted trends within the rain season for both examined periods, we concluded that similar patterns to the respective annual ones appear, indicating that the observed variability of precipitation within the rain season significantly weights the annual precipitation variability in the Mediterranean.

These findings are in agreement with the results of other researchers. The eastern Mediterranean shows a tendency towards drier conditions (Kutiel et al., 1996; Turkes, 1998), while the western and central areas, although showing negative trends in the number of wet days and/or the total rainfall amounts, indicate an increase in intense precipitation events over the period 1951-1996 (Brunetti et al., 2001; Alpert et al., 2002). Schonwiese et al. (1994) reported a pronounced significant trend towards a drier winter climate in the eastern
Mediterranean area for the period 1961-1990. For Italy, recent studies confirm a negative precipitation trend (Buffoni et al., 1999; Piervitali et al., 1998), steeper in the central and southern areas. The west-central Mediterranean area has experienced a precipitation decrease during the last $50 \mathrm{yr}$ (Piervitali et al., 1997).

Table 1 presents the trends of the time series of annual precipitation totals and annual number of rain days for the available Mediterranean stations. Additionally, the trends of area average of annual precipitation totals (1951-2010), as well as the trends of annual number of rain days (19652010) from representative meteorological stations, for west, central and east Mediterranean were calculated (Table 1, bottom lines). Concerning the trends of annual precipitation totals, additional figures in brackets refer to trends for the period 1951-2010. The asterisk (*) denotes statistically significant figures at $95 \%$ confidence level. More specifically, on one hand, the estimated time series of area average annual precipitation totals within the west Mediterranean (Gibraltar, 

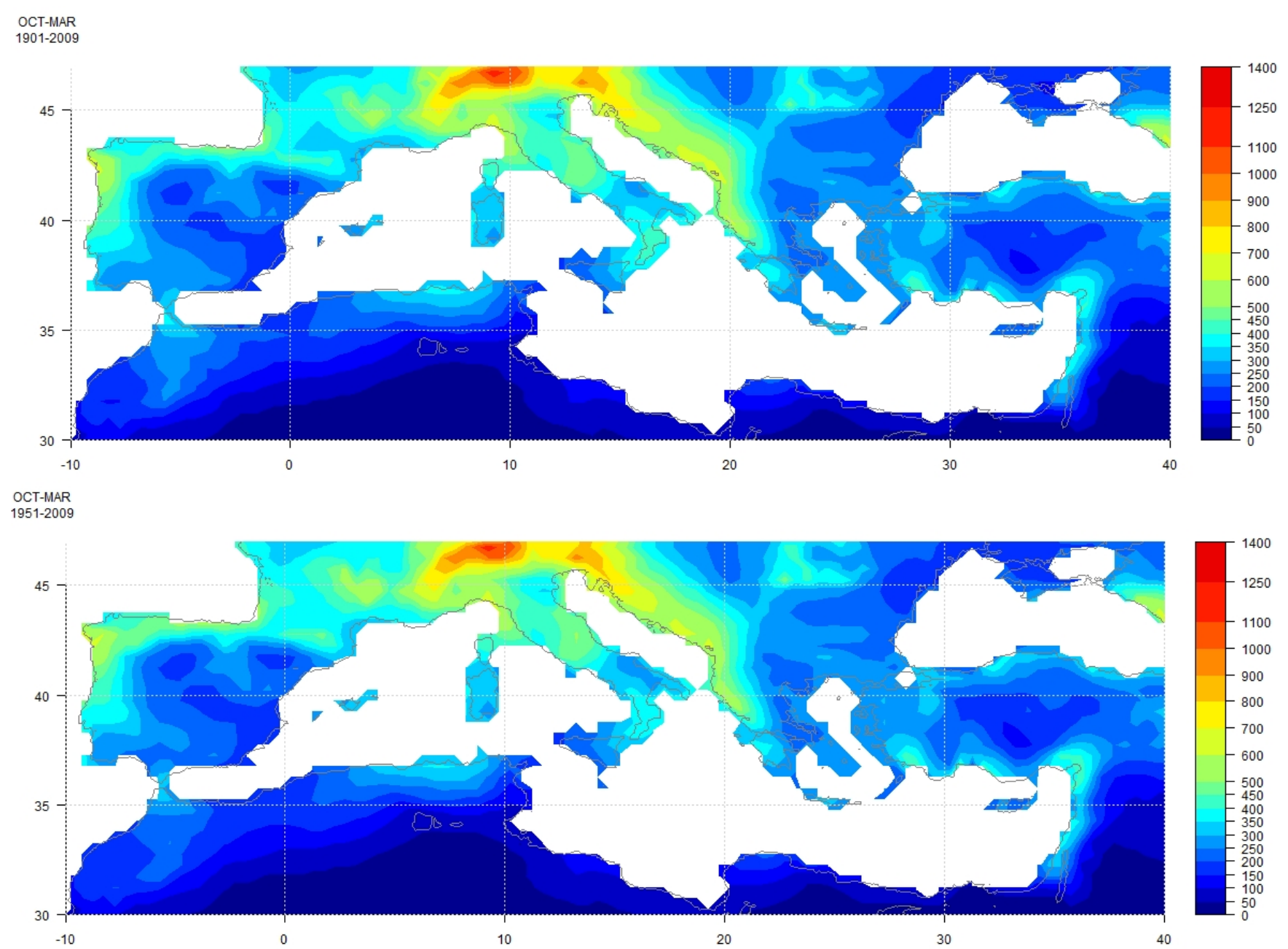

Fig. 2. Spatial distribution of mean precipitation for the rain season (October-March) concerning gridded datasets (CRU TS 3.1), for 19012009 (upper graph) and 1951-2009 (lower graph).

Alicante, Menorca, Barcelona, Perpinian, Ajjacio, Nice), the central Mediterranean (Malta, Tunis, Oran, Kerkyra, Argostoli, Agrinio, Araxos, Methoni, Chania) and east Mediterranean (Athens, Kalamata, Naxos, Rhodes, Sitia, Heraklion, Antalya, Larnaca) are depicted in Fig. 5 (left graphs). On the other hand, the estimated time series of area average annual number of rain days within the west Mediterranean (Menorca, Gibraltar, Alicante, Barcelona), the central Mediterranean (Malta, Trapani, Tunis, Messina, Kerkyra) and east Mediterranean (Athens, Heraklion, Rhodes, Kalamata, Antalya) for the period 1965-2010 are depicted in Fig. 5 (right graphs). In this point, it is worthy to note that the trends of the composite time series should not be considered as a mean trend for the respective geographical area but, as it has been mentioned before, as representative trends of the west, central and east Mediterranean regions, based on ground-based observations.
The resulted composite time series from representative stations within west, central and east Mediterranean show similar trend patterns with those of gridded time series. In west Mediterranean, annual precipitation total within the period 1951-2010 appear a sharp decrease of $28 \%$ (statistically significant at $95 \%$ CL, Table 1), while this decrease is smaller $(23 \%)$ in the central Mediterranean. Insignificant decreasing trends $(13 \%)$ appear in the east Mediterranean (Table 1). Concerning the trends of annual precipitation totals in Greece (not shown), statistically significant (95\% CL) decrease of approximately $10 \%-25 \%$ appear within the period $1951-$ 2010 (Table 1), following the pattern of west Mediterranean. Similar results were found by Feidas et al. (2007), who concluded that the clear decreasing trend in annual precipitation in Greece for the period 1955-2001 is driven by the relative decreasing trend in winter precipitation.

These findings are in agreement with the results of other researchers working on reconstruction of precipitation time 

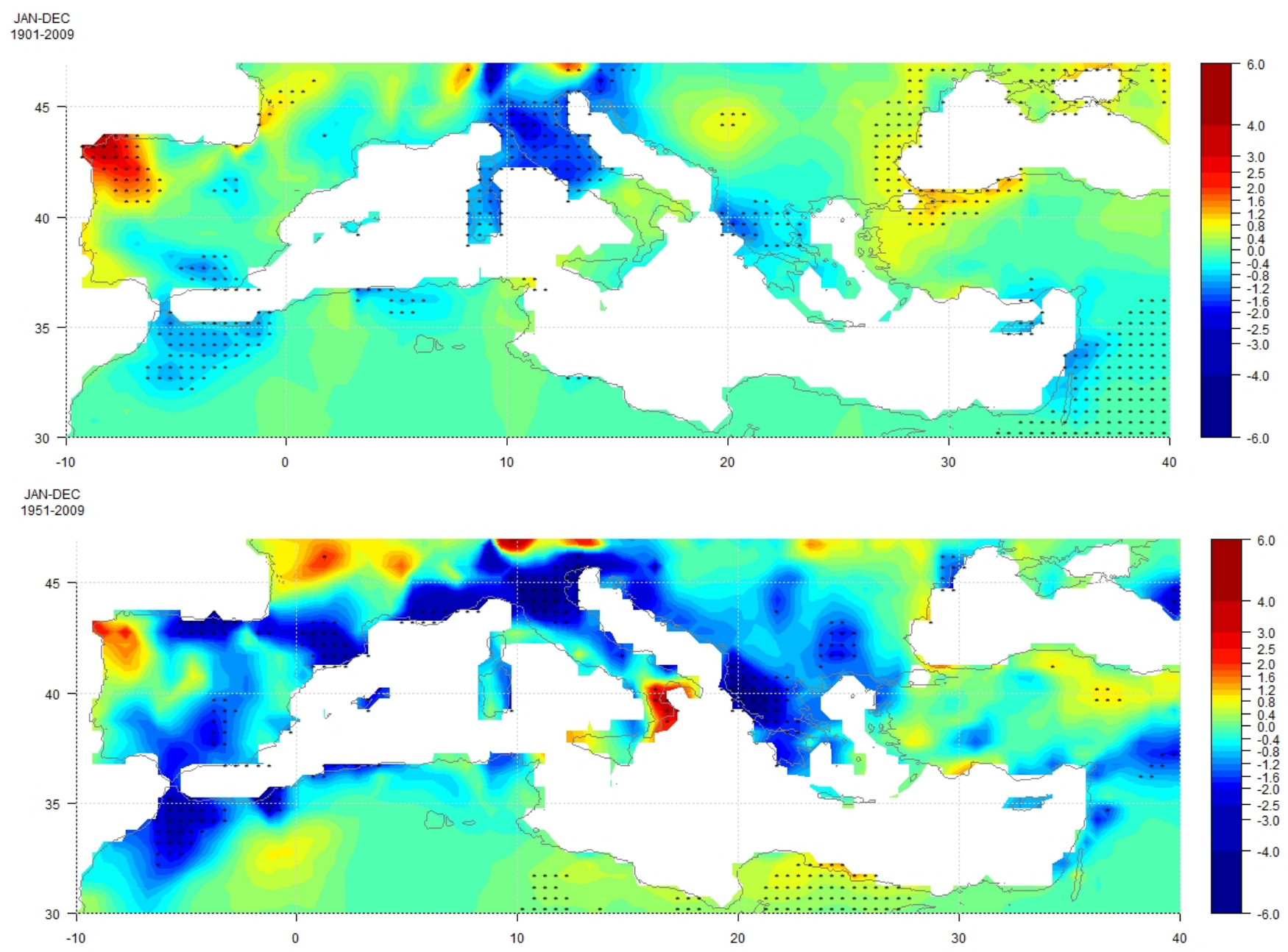

Fig. 3. Spatial distribution of annual precipitation trends concerning gridded datasets (CRU TS 3.1), for 1901-2009 (upper graph) and 1951-2002 (lower graph).

series within the Mediterranean from 1500 to 2002 (Luterbacher et al., 2005). There is clear evidence of an extended dry period (reference period: 1961-1990) at the turn of the twentieth century, followed by wet conditions with the maximum in the decade of 1960 (Xoplaki et al., 2004). The negative trend in winter precipitation totals since the beginning of 1960 (Cullen and deMenocal, 2000; Goodess and Jones, 2002; Xoplaki et al., 2004) appears to be unprecedented as resulted from long time series of reconstructed precipitation.

Figure 5 (right graphs) presents the time series of composite annual number of rain days (days with precipitation greater than $1 \mathrm{~mm}$ ) from representative ground-based stations within the west, central and east Mediterranean. A decrease of $17 \%$, statistically significant $(95 \%$ confidence level) during the period 1951-2010, appears in representative meteorological stations of east Mediterranean, while the trends are insignificant for west and central Mediterranean.
The area average of precipitation totals (1951-2010), as well as the number of rain days (1965-2010), within the rain season (October-March) from representative meteorological stations, for west, central and east Mediterranean appear in Fig. 6. In west Mediterranean, the precipitation totals within the period 1951-2010 appear a sharp decrease of 30\% (statistically significant at $95 \% \mathrm{CL}$ ), while this decrease is smaller $(24 \%)$ in the central Mediterranean. Insignificant decreasing trends $(12 \%)$ appear in the east Mediterranean. Figure 6 (right graphs) presents the time series of composite number of rain days (days with precipitation greater than $1 \mathrm{~mm}$ ) within the rain season. A decrease of $15 \%$, statistically significant $(95 \%$ confidence level) during the period 1951-2010, appears in representative meteorological stations of east Mediterranean, while the trends are insignificant for west and central Mediterranean. The analysis shows that the variability of precipitation totals as the number of rain days within the rain season interprets most of the annual 

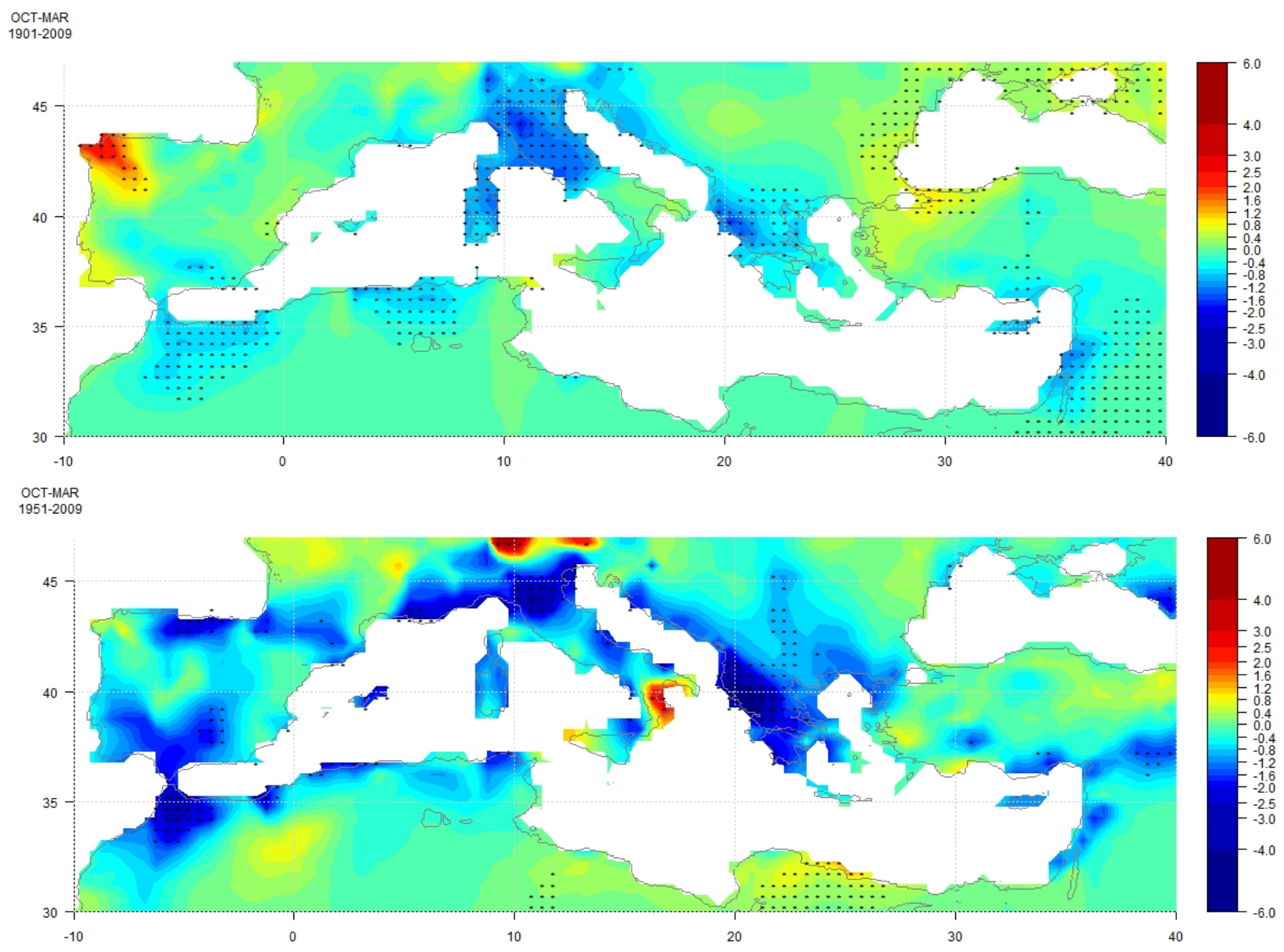

Fig. 4. Spatial distribution of precipitation trends for the rain season (October-March) concerning gridded datasets (CRU TS 3.1), for 1901-2009 (upper graph) and 1951-2009 (lower graph).

variability of these parameters, indicating that the trends in rain season are drivers for the annual trends in the Mediterranean.

Nastos (2008) found that the annual number of rain days in Greece follow decreasing trends for the period 1956-2002, statistically significant (95\% CL). This decrease is higher in western and northern Greece, resulting in some cases in increasing precipitation intensity $\left(\mathrm{mm} \mathrm{day}^{-1}\right)$ (Nastos and Zerefos, 2007, 2008). Moreover, Brunetti et al. (2001) provided evidence that significant decreasing trends in annual number of rain days in Italy exist, while increasing trends in the precipitation intensity $\left(\mathrm{mm}\right.$ day $\left.^{-1}\right)$, statistically significant for northern Italy, appear.

The aforementioned negative trends in precipitation totals can be explained, at least partly, by the observed positive trend in the NAOI (Dünkeloh and Jacobeit, 2003; Xoplaki et al., 2004; Luterbacher et al., 2005). Positive NAOI phase (stronger dipole) results in prevailing westerly winds that are strengthened and moved northwards causing increased precipitation and temperatures over the northern Europe and drier and cooler anomalies in the Mediterranean region, while opposite conditions occur during the negative (weaker dipole) NAOI phase (Hurrell, 1995; Hurrell and Van Loon, 1997; Xoplaki et al., 2000; Feidas et al., 2004). The effect of NAOI in ground based precipitation totals and number of rain days time series is analyzed by means of correlation coefficients concerning the entire year (January-December) and the rainy season (October-March), as well (Table 2). Accordingly, Fig. 7 depicts the correlation between NAOI and gridded precipitation datasets (CRU TS 3.1) for the entire year and the rainy season.

Statistically significant (95\% CL) negative correlations $(-0.30$ to -0.70$)$ between gridded annual precipitation and NAOI throughout the Mediterranean appear, particularly in the western and northern regions, during the period 19012009. Insignificant correlations appear in northern regions of Africa (Algeria), Middle East and southern Turkey, while statistically significant positive correlation $(-0.25$ to -0.35$)$ 

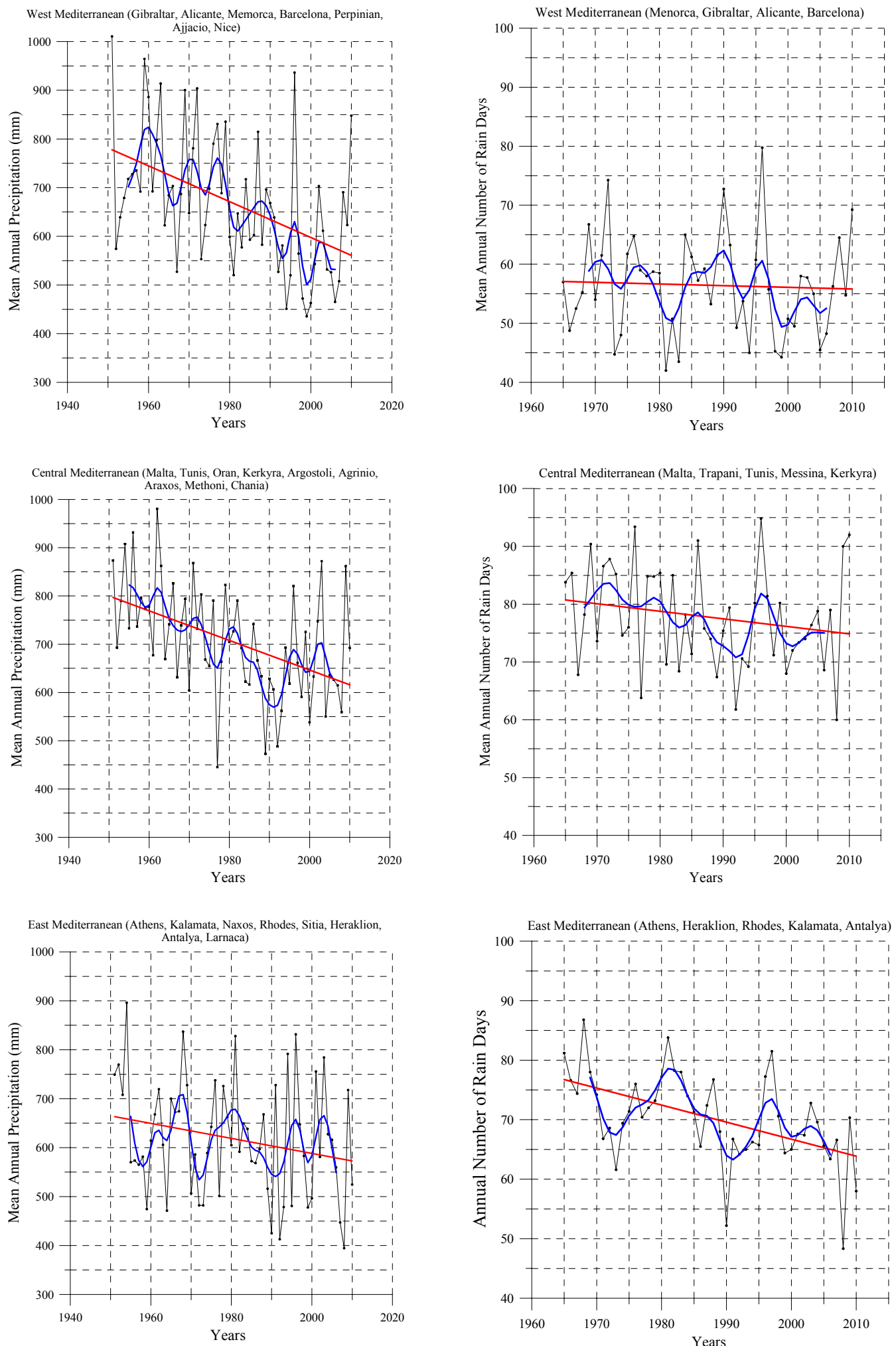

Fig. 5. Composite annual precipitation (left graphs) and annual number of rain days (right graphs) from representative stations of the west (upper), central (middle) and east (lower) Mediterranean region, along with 9-yr Gaussian filter (blue line) and linear trend (red line). 

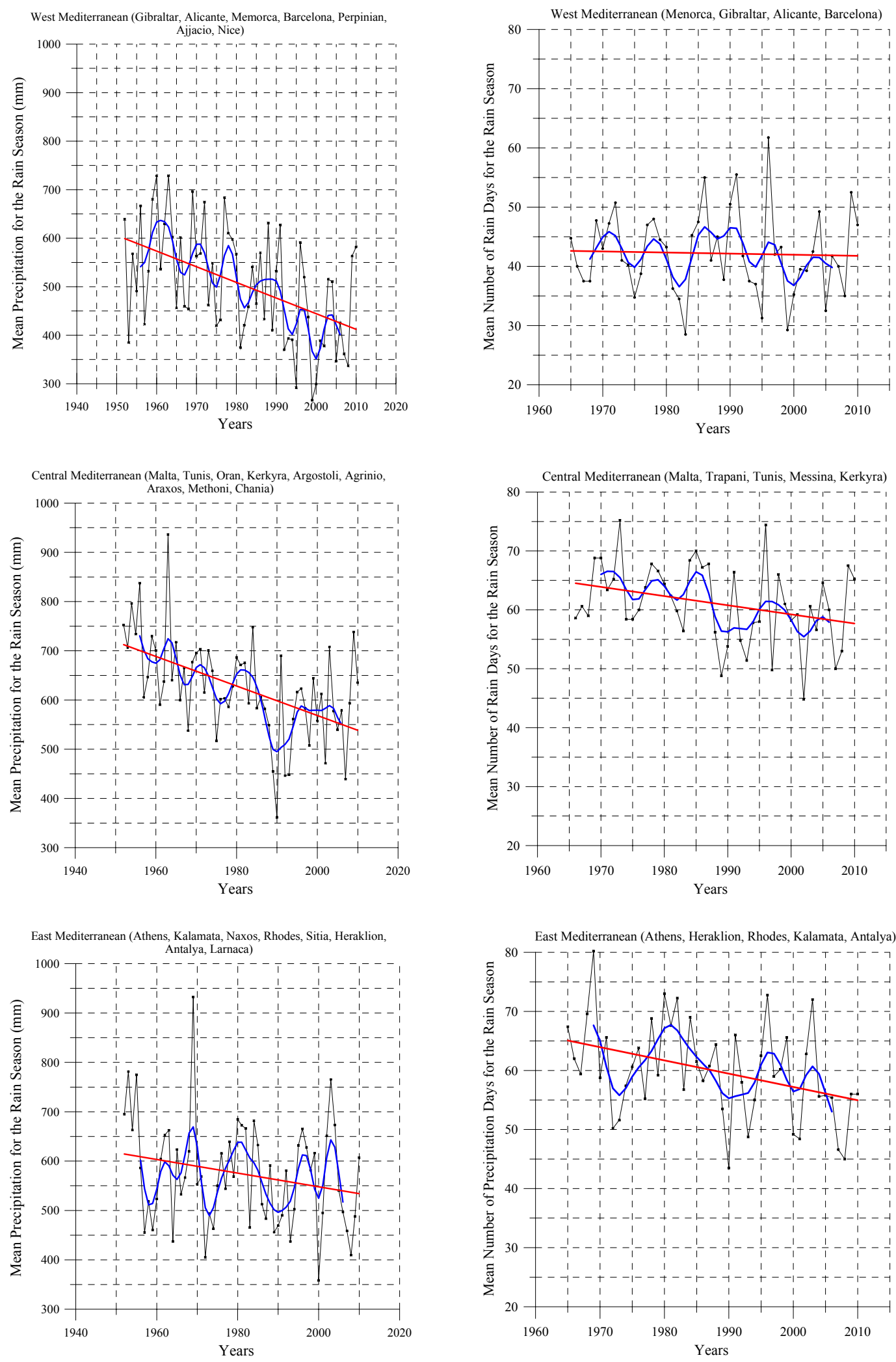

Fig. 6. Composite precipitation (left graphs) and number of rain days (right graphs) for the rain season (October-March) from representative stations of the west (upper), central (middle) and east (lower) Mediterranean region, along with 9-yr Gaussian filter (blue line) and linear trend (red line). 

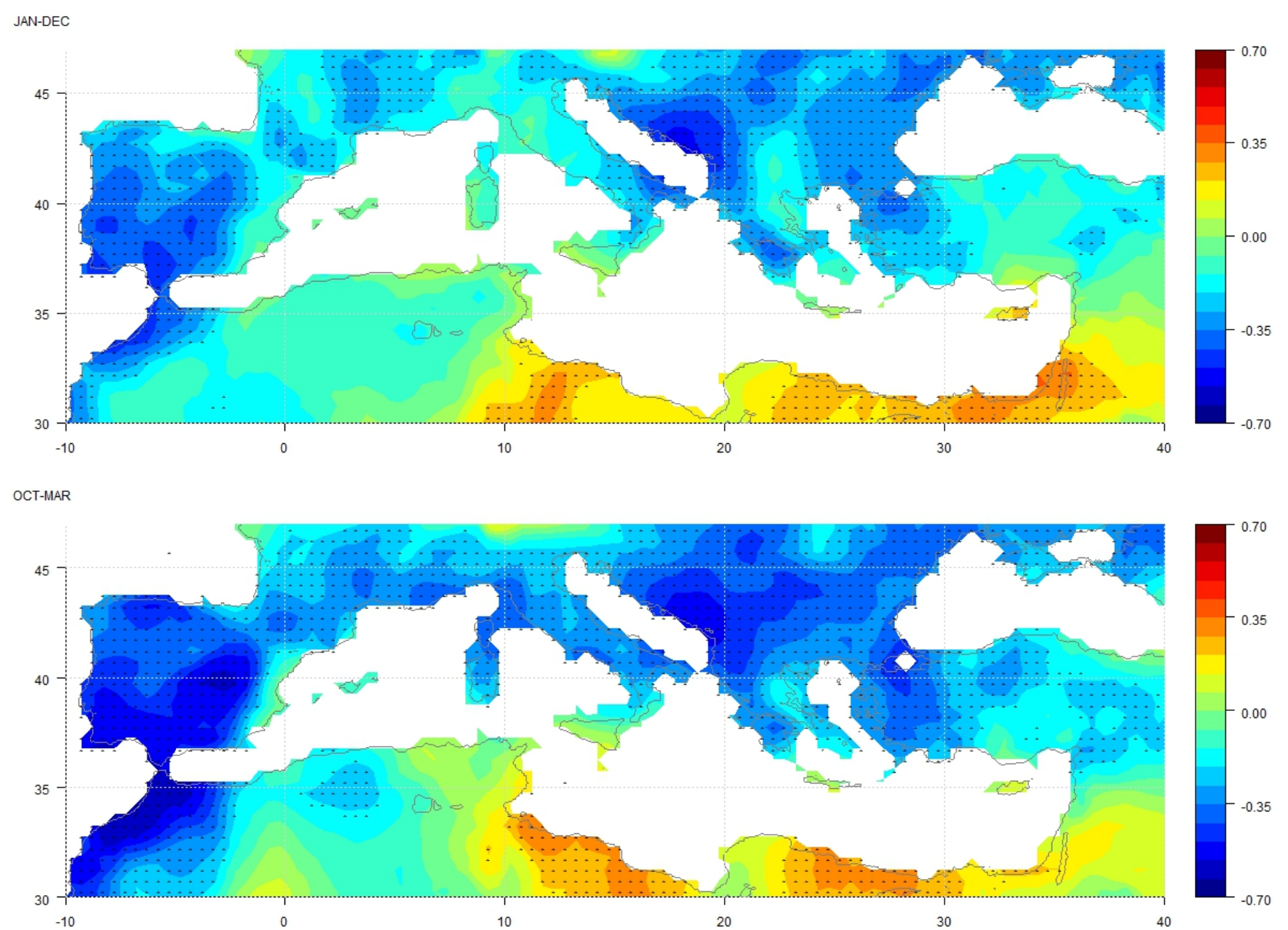

Fig. 7. Correlation coefficients between NAOI and gridded precipitation datasets (CRU TS 3.1) for the entire year (January-December, upper graph) and rainy season (October-March, lower graph). The asterisks denote statistically significant correlations (95\% CL).

appear between $10^{\circ} \mathrm{E}-35^{\circ} \mathrm{E}$ at northern Africa (Fig. 7, upper graph). Higher correlations appear during the rainy season, covering wider areas of Mediterranean (Fig. 7, lower graph). Also, taking into account the ground based annual precipitation totals (Table 2), the west Mediterranean appears negative correlations $(-0.25)$ statistically significant at $95 \% \mathrm{CL}$, the central Mediterranean appears insignificant small negative correlations $(-0.15)$, while the east Mediterranean appears significant negative correlations $(-0.29)$. However, concerning the precipitation totals within the rain season (October-March), the west Mediterranean turns into statistically significant higher negative correlation $(-0.49)$, the central Mediterranean appears insignificant small negative correlations $(-0.19)$, while the east Mediterranean appears significant negative correlations $(-0.39)$. In western Greece the correlation is -0.38 while in the eastern Greece is -0.21 , statistically significant at $95 \% \mathrm{CL}$.

As far as the correlations between NAOI and rain days during the entire year are concerned, statistically significant $(95 \% \mathrm{CL})$ negative correlations $(-0.32)$ appear only within western Mediterranean (Table 2), while statistically significant $(95 \% \mathrm{CL})$ higher negative correlations appear during the rainy season for the west $(-0.57)$, central $(-0.38)$ and east ( -0.43$)$ Mediterranean.

\subsection{Trends and variability based on future model projections}

In the process, the climatic changes of mean annual precipitation totals within the Mediterranean region between the period 1961-1990 (reference period) and the period 2071-2100 (future climate) are presented (Fig. 8) using climate model simulations (RACMO2.1/KNMI, van Meijgaard et al., 2008). The future climate projections were based on SRES A1B. The Regional Climate Simulation Model (RACMO2.1/KNMI) was selected due to better specific metrics, briefly presented below. The ENSEMBLES Regional Climate Model weights are based on the following specific metrics, deduced from the ERA40 reanalysis driven simulations at $25 \mathrm{~km}$ (ENSEMBLES Deliverable D3.2.2): 
$1961-1990$

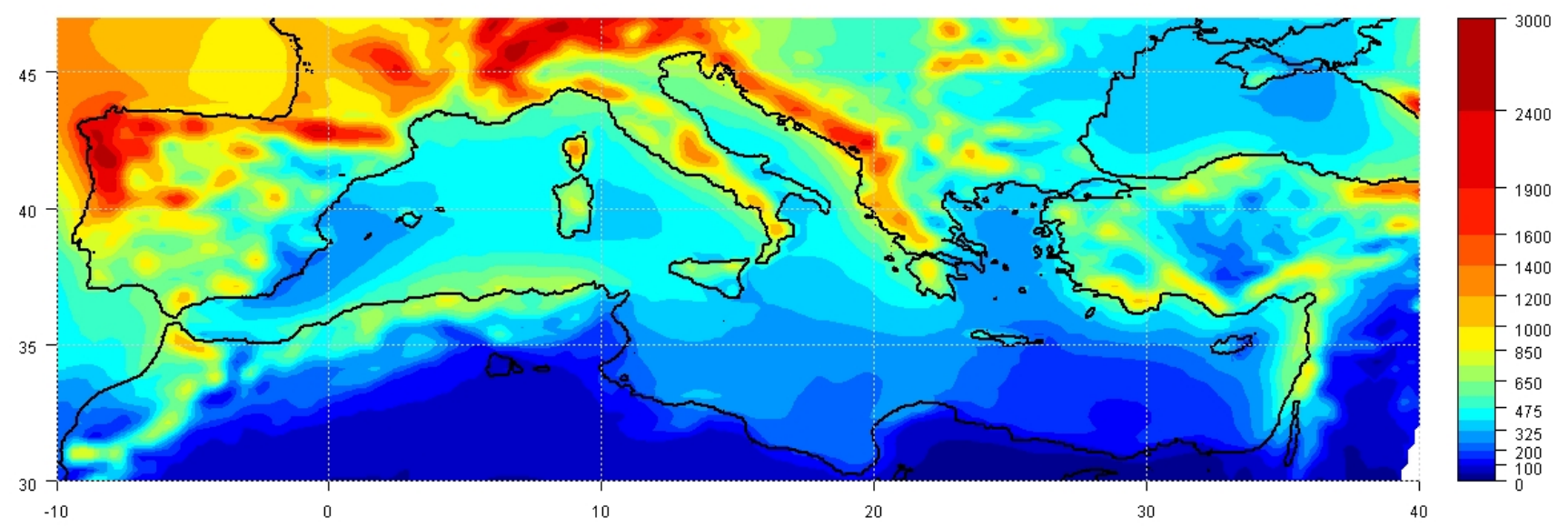

$2071-2100$

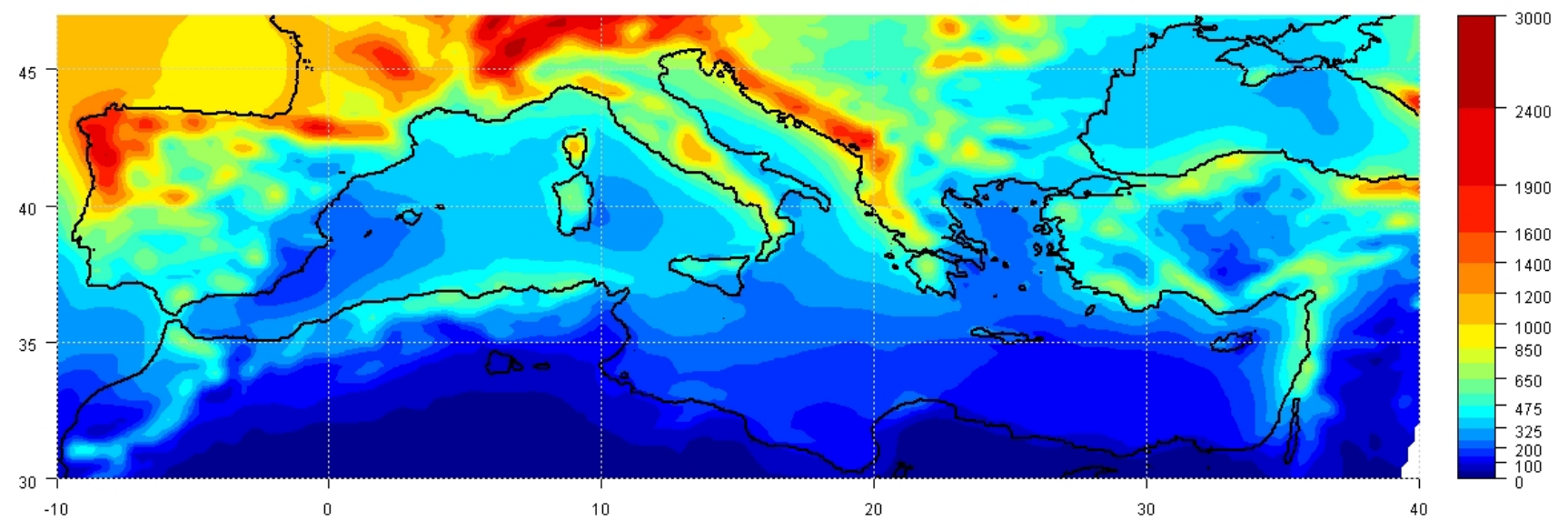

$\%$ Change

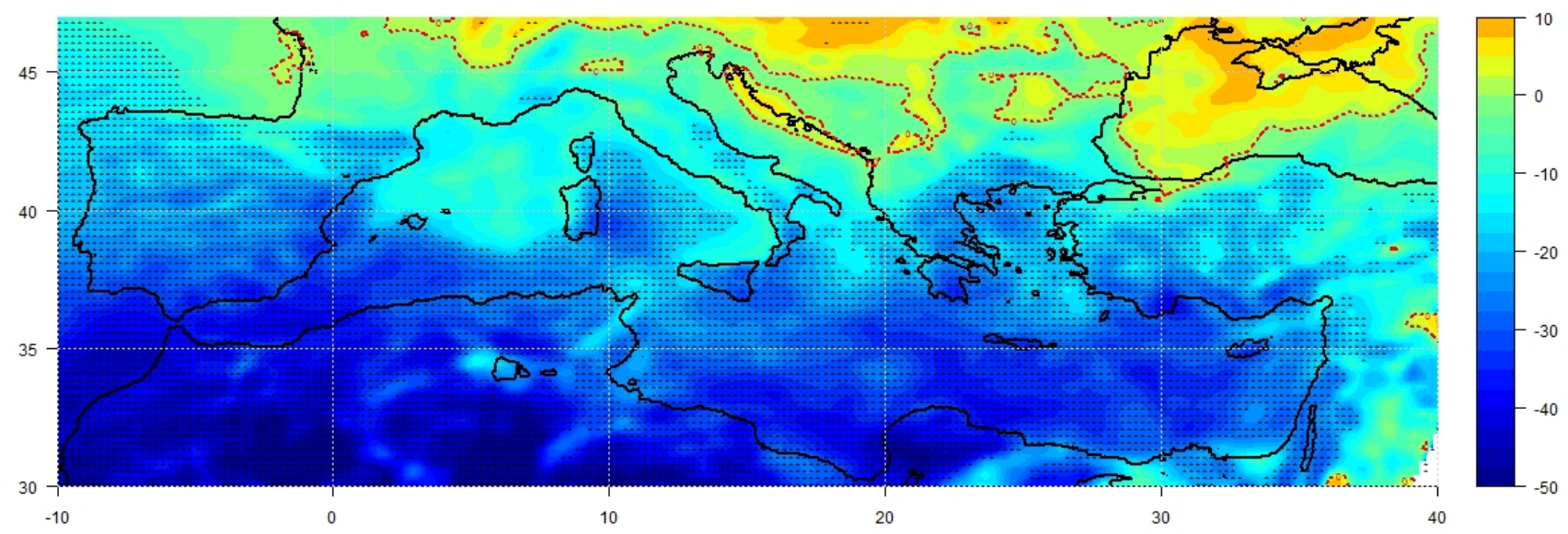

Fig. 8. Spatial distribution of mean annual precipitation totals $(\mathrm{mm})$ for the reference period 1961-1990 (upper graph), the future period 2071-2100 (middle graph) and the differences of mean annual precipitation between the two periods (lower graph). Shaded areas concern statistically significant differences ( $95 \% \mathrm{CL}$ ). 
Table 2. Correlation coefficients of NAOI with precipitation totals (1951-2010) and number of rain days (1965-2010) for the entire year (January-December) and the rain season (October-March). The asterisk $\left(^{*}\right)$ denotes statistically significant figures at $95 \%$ confidence level.

\begin{tabular}{|c|c|c|c|c|c|c|c|}
\hline & Station & Longitude & Latitude & $\begin{array}{r}\text { Precipitation } \\
\text { (January-December) }\end{array}$ & $\begin{array}{r}\text { Precipitation } \\
(\text { October-March) }\end{array}$ & $\begin{array}{l}\text { Number of rain days } \\
\text { (January-December) }\end{array}$ & $\begin{array}{r}\text { Number of rain days } \\
\text { (October-March) }\end{array}$ \\
\hline 1 & Gibraltar & -5.12 & 36.09 & $-0.48^{*}$ & $-0.53^{*}$ & $-0.49 *$ & $-0.55^{*}$ \\
\hline 2 & Alicante & -0.30 & 38.22 & 0.00 & 0.05 & -0.17 & -0.19 \\
\hline 3 & Oran & 0.36 & 35.38 & -0.07 & -0.08 & & \\
\hline 4 & Barcelona & 2.09 & 41.24 & -0.06 & -0.18 & -0.06 & $-0.34 *$ \\
\hline 5 & Perpinian & 2.53 & 42.44 & -0.08 & $-0.34^{*}$ & & \\
\hline 6 & Menorca & 4.14 & 39.52 & -0.25 & -0.13 & $-0.33^{*}$ & $-0.31 *$ \\
\hline 7 & Nice & 7.12 & 43.39 & -0.15 & $-0.28^{*}$ & & \\
\hline 8 & Ajjacio & 8.48 & 41.55 & -0.10 & $-0.29 *$ & & \\
\hline 9 & Tunis & 10.14 & 36.50 & 0.04 & -0.04 & -0.06 & -0.17 \\
\hline 10 & Trapani & 12.30 & 37.55 & 0.16 & -0.07 & -0.19 & $-0.40^{*}$ \\
\hline 11 & Malta & 14.29 & 35.51 & 0.01 & 0.05 & -0.15 & -0.02 \\
\hline 12 & Messina & 15.33 & 38.12 & $-0.53^{*}$ & -0.32 & $-0.39 *$ & $-0.47^{*}$ \\
\hline 13 & Kerkyra & 19.55 & 39.37 & -0.23 & $-0.34 *$ & $-0.31 *$ & $-0.56^{*}$ \\
\hline 14 & Ioannina & 20.49 & 39.42 & $-0.33^{*}$ & $-0.41^{*}$ & $-0.32 *$ & $-0.59^{*}$ \\
\hline 15 & Argostoli & 20.50 & 38.12 & -0.05 & $-0.30^{*}$ & & \\
\hline 16 & Agrinio & 21.23 & 38.37 & -0.20 & $-0.35^{*}$ & $-0.34 *$ & $-0.52 *$ \\
\hline 17 & Araxos & 21.42 & 38.15 & -0.25 & $-0.37^{*}$ & $-0.42 *$ & $-0.59 *$ \\
\hline 18 & Methoni & 21.42 & 36.50 & 0.02 & $-0.36^{*}$ & & \\
\hline 19 & Rhodes & 21.44 & 36.24 & 0.00 & -0.17 & -0.18 & $-0.41^{*}$ \\
\hline 20 & Kozani & 21.50 & 40.18 & -0.07 & $-0.44^{*}$ & -0.18 & $-0.39^{*}$ \\
\hline 21 & Kalamata & 22.01 & 37.04 & -0.12 & $-0.38^{*}$ & $-0.31^{*}$ & $-0.63^{*}$ \\
\hline 22 & Samos & 22.01 & 37.42 & -0.13 & $-0.28^{*}$ & -0.21 & $-0.41^{*}$ \\
\hline 23 & Larissa & 22.25 & 39.38 & 0.03 & -0.20 & -0.11 & $-0.47 *$ \\
\hline 24 & Tripolis & 22.40 & 37.52 & $-0.28 *$ & $-0.46^{*}$ & $-0.41^{*}$ & $-0.55^{*}$ \\
\hline 25 & Thessaloniki & 22.57 & 40.37 & -0.25 & $-0.45^{*}$ & $-0.36^{*}$ & $-0.68 *$ \\
\hline 26 & Kythira & 22.98 & 36.15 & -0.21 & -0.22 & -0.12 & $-0.49 *$ \\
\hline 27 & Athens (NOA) & 23.43 & 37.58 & -0.17 & $-0.37^{*}$ & $-0.45^{*}$ & $-0.59^{*}$ \\
\hline 28 & Helliniko & 23.44 & 37.54 & -0.16 & $-0.26^{*}$ & -0.18 & -0.15 \\
\hline 29 & Skyros & 24.48 & 38.97 & -0.22 & $-0.35^{*}$ & & \\
\hline 30 & Limnos & 25.04 & 39.53 & -0.19 & $-0.30^{*}$ & -0.28 & $-0.45^{*}$ \\
\hline 31 & Heraklion & 25.11 & 35.20 & -0.10 & -0.25 & -0.05 & $-0.36^{*}$ \\
\hline 32 & Naxos & 25.37 & 37.10 & -0.23 & $-0.34 *$ & & \\
\hline 33 & Alexandroupolis & 25.95 & 40.85 & $-0.27^{*}$ & $-0.43^{*}$ & $-0.34^{*}$ & $-0.43^{*}$ \\
\hline 34 & Canakale & 26.24 & 40.08 & $-0.37 *$ & $-0.43^{*}$ & $-0.46^{*}$ & $-0.33^{*}$ \\
\hline 35 & Edirne & 26.34 & 41.40 & $-0.28 *$ & $-0.39 *$ & $-0.39 *$ & $-0.44^{*}$ \\
\hline 36 & Mytilini & 26.6 & 39.05 & -0.23 & -0.18 & $-0.37 *$ & -0.16 \\
\hline 37 & Mougla & 28.22 & 37.13 & -0.21 & $-0.38^{*}$ & -0.22 & -0.27 \\
\hline 38 & Isparta & 30.33 & 37.45 & $-0.35^{*}$ & $-0.57^{*}$ & $-0.37^{*}$ & $-0.48^{*}$ \\
\hline 39 & Antalya & 30.44 & 36.52 & -0.18 & $-0.38^{*}$ & -0.22 & -0.28 \\
\hline \multirow[t]{4}{*}{40} & Larnaca & 33.38 & 34.53 & 0.12 & -0.16 & & \\
\hline & West Mediterranean & & & $-0.25 *$ & $-0.49^{*}$ & $-0.32 *$ & $-0.57 *$ \\
\hline & Central Mediterranean & & & -0.15 & -0.19 & -0.27 & $-0.38^{*}$ \\
\hline & East Mediterranean & & & $-0.29 *$ & $-0.39^{*}$ & -0.07 & $-0.43^{*}$ \\
\hline
\end{tabular}

f1: large scale circulation based on a weather regime classification

f2: meso-scale signal based on seasonal temperature and precipitation analysis

f3: probability density distribution match of daily and monthly temperature and precipitation analysis

f4: extremes in terms of re-occurrence periods for temperature and precipitation f5: trend analysis for temperature

f6: representation of the annual cycle in temperature and precipitation

The weights $f 1, f 2, \ldots, f 6$ are combined to a single number by multiplication. Following this procedure, the RACMO2/KNMI model has a weight of 465 compared with 81 for REMO/MPI and 86 for the HadRM3/Hadley Centre model. The largest overall weight is associated with the model of KNMI, mostly as a result of the function $\mathrm{f} 4$ 
(representation of extremes), which shows the largest variability across models and the function $\mathrm{f} 2$ (meso-scale signal based on seasonal temperature and precipitation analysis), which shows the best score (0.093) from all the other models. Hence, we chose to use the RACMO2/KNMI for the calculation of mean seasonal precipitation in the future climate. The results are depicted in Fig. 8, showing the spatial distribution of mean annual precipitation totals $(\mathrm{mm})$ for the reference period (1961-1990, upper graph) and future period (20712100 , middle graph) and the differences $(\%)$ in mean annual precipitation between the two periods (lower graph). A decrease of about $20 \%$ (statistically significant at $95 \%$ CL) in annual precipitation appears throughout the Mediterranean region with an exception of eastern regions of France, Dalmatian coasts, northern Balkans (Romania, Northern Serbia, Croatia), some parts of Bulgaria and Black Sea, showing a small increase $(1 \%-6 \%)$ for the future period against negligible changes in northern Italy, France and central Balkans. Particularly, a significant decrease (30\%-45\%) is shown on the majority of northern Africa, while a significant decrease appears from $10 \%$ at the northern to $30 \%$ at the southern parts of Iberian Peninsula, Greece and Turkey.

Moreover, these findings are in agreement with the decrease in precipitation within the Mediterranean presented by 21 Multi-Model data set (MMD), where the percent decrease in mean annual precipitation from the years 19801999 to 2080-2099 under the A1B scenario, averaging over all available simulations for each model ranges from $-15 \%$ to $-50 \%$ (IPCC, 2007).

\section{Conclusions}

The annual precipitation totals from ground-based observations and gridded datasets (CRU TS 3.1) appear statistically significant (95\% confidence level) decreasing trends in the majority of Mediterranean regions during the period 19012009, much more pronounced during the period 1951-2009 and within the rain season (October-March). An exception appears in northern Africa and western Iberian peninsula, where negligible increasing trends (not statistically significant at $95 \% \mathrm{CL}$ ), are apparent. On the other hand, concerning the annual number of rain days, significant decreasing trends appear within the east Mediterranean, while the trends are insignificant for west and central Mediterranean during the period 1951-2008.

The North Atlantic Oscillation influences negatively the precipitation totals and the number of rain days mainly in Spain, southern France, Italy and Greece. These correlations are higher within the rain season (October-March) than the entire year. Based on the future projections of regional climate model RACMO2/KNMI, annual precipitation within the majority of Mediterranean is very likely to decrease on an average of $20 \%$, during the period 2071-2100 compared to 1961-1990 under SRES A1B.
Acknowledgements. The authors would like to thank the two unknown reviewers for their constructive criticism and comments.

Edited by: A. Bartzokas

Reviewed by: two anonymous referees

\section{References}

Alpert, P., Ben-Gai, T., Baharad, A., Benjamini, Y., Yekutieli, D., Colacino, M., Diodato, L., Ramis, C., Homar, V., Romero, R., Michaelides, S., and Manes, A.: The paradoxical increase of Mediterranean extreme daily rainfall in spite of decrease in total values, Geophys. Res. Lett., 29, 311-314, 2002.

Brunetti, M., Maugeri, M. F., and Nanni, T.: Changes in total precipitation, rainy days and extreme events in northeastern Italy, Int. J. Climatol., 21, 861-871, 2001.

Brunetti, M., Caloiero, T., Coscarelli, R., Gullà, G., Nanni, T., and Simolo, C.: Precipitation variability and change in the Calabria region (Italy) from a high resolution daily dataset, Int. J. Climatol., doi:10.1002/joc.2233, online first, 2010.

Buffoni, L., Maugeri, M., and Nanni, T.: Precipitation in Italy from 1833 to 1996, Theor. Appl. Climatol., 63, 33-40, 1999.

Cullen, H. M. and deMenocal, P. B.: North Atlantic influence on Tigris- Euphrates stream flow, Int. J. Climatol., 20, 853-863, 2000.

Dünkeloh, A. and Jacobeit, J.: Circulation dynamics of Mediterranean precipitation variability 1948-98, Int. J. Climatol., 23, 1843-1866, 2003.

ENSEMBLES Deliverable D3.2.2: RCM-specific weights based on their ability to simulate the present climate, calibrated for the ERA40-based simulations, available at: www.ensembleseu.org (last access: 20 February 2011), 2011.

Feidas, H., Noulopoulou, N., Makrogiannis, T., and Bora-Senta, E.: Trend analysis of precipitation time series in Greece and their relationship with circulation using surface and satellite data: 19552001, Theor. Appl. Climatol., 87, 155-177, 2007.

Folland, C. K. and Karl, T. R.: Observed climate variability and change. In Climate Change 2001: The Scientific Basis. Contribution of Working Group 1 to the Third IPCC Scientific Assessment, edited by: Houghton, J. T., Ding, Y., Griggs, D. J., Noguer, M., van der Linden, P. J., Dai, X., Maskell, K., and Johnson, C. A. , Cambridge University Press, Cambridge, United Kingdom and New York, NY, USA, 99-181, 2001.

Forland, E., van Engelen, A., Hanssen-Bauer, I., Heino, R., Ashcroft, J., Dahlström, B., Demarée, G., Frich, P., Jónsson, T., Mietus, M., Müller-Westermeier, G., Pálsdottir, T., Tuomenvirta, H., and Vedin, H.: Changes in "normal" precipitation in the North Atlantic region, Klima Report 7/96, The Norwegian Meteorological Institute, Oslo, 1996.

Goodess, C. M. and Jones, P. D.: Links between circulation and changes in the characteristics of Iberian rainfall, Int. J. Climatol., 22, 1593-1615, 2002.

Guijarro, J. A., Jansà, A., and Campins, J.: Time variability of cyclonic geostrophic circulation in the Mediterranean, Adv. Geosci., 7, 45-49, doi:10.5194/adgeo-7-45-2006, 2006.

Hurrell, J. W.: Decadal trends in the North Atlantic Oscilation: Regional temperatures and precipitation, Science, 269, 676-679, 1995. 
Hurrell, J. W. and Van Loon, H.: Decadal variations in climate associated with the North Atlantic oscillation, Clim. Change, 36, 301-326, 1997.

IPCC: The Physical Science Basis. Contribution of Working Group 1 to the Fourth IPCC Assessment Report, Chapter 11 Regional Climate Projections, 2007.

Jones, P. D., Jónsson, T., and Wheeler, D.: Extension to the North Atlantic Oscillation using early instrumental pressure observations from Gibraltar and South-West Iceland, Int. J. Climatol., 17, 1433-1450, 1997.

Karl, T. and Knight, R.: Secular trends of precipitation amount frequency and intensity in the United States, Bull. Am. Met. Soc., 79, 232-241, 1998.

Kutiel, H., Maheras, P., and Guika, S.: Circulation and extreme rainfall conditions in the eastern Mediterranean during the last century, Int. J. Climatol., 16, 73-92, 1996.

Lenderink, G, van den Hurk, B., van Meijgaard, E., van Ulden, A. P., and Cuijpers, J. H.: Simulation of present-day climate in RACMO2: first results and model developments, KNMI Technical Report 252, 24 pp., 2003.

Lionello, P., Dalan, F., and Elvini, E.: Cyclones in the Mediterranean Region: the present and the doubled $\mathrm{CO}_{2}$ climate scenarios, Clim. Res., 22, 147-159, 2002.

Lionello, P., Bhend, J., Buzzi, A., Della-Marta, P. M., Krichak, S., Jans ̃̃, A., Maheras, P., Sanna, A., Trigo, I. F., and Trigo, R.: Cyclones in the Mediterranean region: climatology and effects on the environment, in: Mediterranean Climate Variability, edited by: Lionello, P., Malanotte-Rizzoli, P., abd Boscolo, R., Amsterdam, Elsevier, Netherlands, 324-372, 2006.

Luterbacher, J., Xoplaki, E., Casty, C., Wanner, H., Pauling, A., Kiittel, M., Rutishauser, T., Bronnimann, S., Fischer, E., Fleitmann, D., Gonzalez-Rouco, F. J., Garcia-Herrera, R., Barriendos, M., Rodrigo, F., Gonzalez-Hidalgo, J. C., Saz, M. A., Gimeno, L., Ribera, P., Brunet, M., Paeth, H., Rimbu, N., Fehs, T., Jacobeit, J., Diinkeloh, A., Zorita, E., Guiot, J., Tiirkes, M., Alcoforado, M. J., Trigo, R., Wheeler, D., Tett, S., Mann, M.E., Touchan, R., Shindell, D. T., Silenzi, S., Montagna, P., Camuffo, D., Mariotti, A., Nanni, T., Brunetti, M., Maugeri, M., Zerefos, C., De Zolt, S., Lionello, P., Nunes, M. F., Rath, V., Beltrami, H., Garnier, E., and Le Roy Ladurie, E.: Chapter 1, Mediterranean Climate Variability Over The Last Centuries: A Review, in: The Mediterranean Climate: an overview of the main characteristics and issues, edited by: Lionello, P., Malanotte-Rizzoli, P., and and Boscolo, R., Elsevier, 2005.

Maheras, P. and Kolyva-Mahera, F.: Temporal and Spatial characreristics of annual precipitation over Balkans in the twentieth century, Int. J. Climatol., 10, 495-504, 1990.

Maheras, P., Flocas, H., Patrikas, I., and Anagnostopoulou, Ch.: A 40 year objective climatology of surface cyclones in the Mediterranean region: Spatial and temporal distribution, Int. J. Climatol., 21, 109-130, 2001.

Mantis, H. T., Repapis, C. C., Philandras, C. M., Paliatsos, A. G., and Amanatidis, G. T.: The spatial and temporal structure of the precipitation climate the Eastern Mediterranean, Background for a study of Climate Change, EUR 17458 - Eastern Europe and Global Change, edited by: Ghazi, A., Mathy, P., and Zerefos, C., Greece, 125-131, 1994.

Metaxas, D. A., Philandras, C. M., Nastos, P. T., and Repapis, C. C.: Variability of Precipitation pattern in Greece during the year,
Fresen. Environ. Bull., 8, 1-6, 1999.

Mitchell, T. D. and Jones P. D.: An improved method of constructing a database of monthly climate observations and associated high-resolution grids, Int. J. Climatol., 25, 693-712, doi:10.1002/joc.1181, 2005.

Nastos, P. T.: Spatial and temporal variation of rain intensity in Greece, in: Proceedings of 8th International Hydrogeological Congress, Athens, Greece, 651-660, 2008.

Nastos, P. T. and Zerefos, C. S.: On extreme daily precipitation totals at Athens, Greece, Adv. Geosci., 10, 59-66, doi:10.5194/adgeo-10-59-2007, 2007.

Nastos, P. T. and Zerefos, C. S.: Decadal changes in extreme daily precipitation in Greece, Adv. Geosci., 16, 55-62, doi:10.5194/adgeo-16-55-2008, 2008.

New, M., Hulme, M., and Jones, P.: Representing TwentiethCentury Space-Time Climate Variability, Part I: Development of a 1961-90 mean monthly terrestrial climatology, J. Climate, 12, 829-856, 1999.

New, M. G., Hulme, M., and Jones, P. D.: Representing twentieth century space time climate fields, Part II: development of a 19011996 mean monthly terrestrial climatology, J. Climate, 13, 2217 2238, 2000.

Paliatsos, A. G., Nastos, P. T., Tzavelas, G., and Panagiotakos, D. B.: Characteristics of precipitation in urban Athens area, from 1891 to 2000, Fresen. Environ. Bull., 14, 422-428, 2005.

Palutikof, J. P., Trigo, R. M., and Adcock, S. T.: Scenarios of future rainfall over the Mediterranean: is the region drying?, in: Proceedings of Mediterranean Desertification, Research Results and Policy Implications, Crete, Greece, 1996.

Piervitali, E., Colasino, M., and Conte, M.: Signals of climatic change in the Central-Western Mediterranean basin, Theor. Appl. Climatol., 58, 211-219, 1997.

Piervitali, E., Colacino, M., and Conte, M.: Rainfall over the central-western Mediterranean basin in the period 1951-1995, Part I: precipitation trends, Il Nuovo Cimento, 21C, 331-344, 1998.

Pnevmatikos, J. D. and Katsoulis, B. D.: The changing rainfall regime in Greece and its impact on climatological means, Meteorol. Appl., 13, 331-345, 2006.

Repapis, C. C.: Temporal fluctuations of precipitation in Greece, Riv. Meteorol. Aeron., XLVI, 19-25, 1986.

Schonwiese, C. and Rapp, J.: Climate Trend Atlas of Europe based on observations 1891-1990, Kluwer Academic Publishers, Dordrecht, 224 pp., 1997.

Schonwiese, C. D., Rapp, J., Fuchs, T., and Denhard, M.: Observed climate trends in Europe 1891-1990, Meteorol. Z., NF 38, 5163, 1994.

Sneyers, R.: Sur l' analyse statistique des series d'observations, Technical Note 143, WMO, Geneva, 1975.

Tiedtke, M.: A comprehensive mass flux scheme for cumulus parameterization in large-scale models, Mon. Weather. Rev., 117, 1779-1800, 1989.

Tiedtke, M.: Representation of clouds in large-scale models, Mon. Wea. Rev., 121, 3040-3061, 1993.

Trigo, I. F., Davies, T. D., and Bigg, G. R.: Decline in Mediterranean rainfall caused by weakening of Mediterranean cyclones, Geophys. Res. Lett., 27, 2913-2916, 2000.

Tselioudis, G., Zerefos, C., Zanis, P., Repapis, C., and Kapspmenakis, I.: Future Trends in Mediterranean Precipitation and Pos- 
sible Connections with the Phase of the North Atlantic Oscillation, Proceedings 9th Conference of Meteorology, Climatology and Atmospheric Physics, Thessaloniki, 28-31 May 2008, 513520, 2008.

Turkes, M.: Influence of geopotential heights, cyclone frequency and Southern oscillation on rainfall variations in Turkey, Int. J. Climatol., 18, 649-680, 1998.

Ulbrich, U. and Christoph, M.: A shift of the NAO and increasing storm track activity over Europe due to anthropogenic greenhouse gas forcing, Clim. Dynam., 15, 551-559, 1999.

van Meijgaard, E., van Ulft, L. H., van de Berg, W. J., Bosveld, F. C., van den Hurk, B. J. J. M., Lenderink, G., and Siebesma, A. P.: The KNMI Regional 844 Atmospheric Climate Model RACMO Version 2.1. KNMI Technical Report, 845 TR-302. KNMI, De Bilt, 2008.
Xoplaki, E., Luterbacher, J., Burkard, R., Patrikas, I., and Maheras, P.: Connection between the large scale $500 \mathrm{hPa}$ geopotential height fields and precipitation over Greece during wintertime, Clim. Res., 14, 129-126, 2000.

Xoplaki, E., González-Rouco, J. F., Luterbacher, J., and Wanner, H.: Wet season Mediterranean precipitation variability: influence of large-scale dynamics and trends, Clim. Dynam., 23, 63-78, doi:10.1007/s00382-004-0422-0, 2004.

Zhang, X., Hogg, W., and Mekis, E.: Spatial and Temporal characteristics of heavy precipitation events in Canada, J. Climate, 14, 1923-1936, 2001. 